Eur. J. Clin. Chem. Clin. Biochem.

Vol. 31, 1993, pp. $447-451$

(C) 1993 Walter de Gruyter \& Co. Berlin - New York

\title{
Establishment of Reference Ranges for Prolactin in Neonates, Infants, Children and Adolescents
}

\author{
By Gudrun Wiedemann and L. Jonetz-Mentzel
}

Klinisch-Chemisches Labor der Klinik und Poliklinik für Kindermedizin der Medizinischen Hochschule, Erfurt, Germany

(Received January 21/March 31, 1993)

Summary: Prolactin was determined in the sera of 686 healthy neonates, infants, children and adolescents (age range 5 days to 18 years), using the IMx from Abbott Laboratories. The applied test was a microparticle enzyme immunoassay (MEIA). The proband collective was divided into 9 age groups, and each age group into males and females. In accordance with the recommendations of the International Federation of Clinical Chemistry, the $95 \%$ scatter range was taken as the reference range. Only a few reference groups showed a normal Gaussian distribution. In addition to the 50 th percentile, the 2.5 th and 97.5 th percentile were calculated for all reference groups, and the minimal and maximal values were also reported. From the age of 12 years onwards, significant differences were found between males and females. The U-test of Mann \& Whitney was used to test for significant differences between individual reference groups. Groups showing no significant differences were combined, and the corresponding reference ranges for serum prolactin were then calculated.

\section{Introduction}

Serum prolactin is measuired in childhood mainly as a means of establishing the presence or absence of increased prolactin secretion.

The causes of hyperprolactinaemia are complex. Particularly important are pituitary tumours or other encroachments on space, which compress the pituitary stem and prevent inhibitory factors from reaching the site of prolactin secretion $(1-3)$.

Excessive prolactin production may not be clearly evident from the basal serum prolactin concentration alone. In such cases, a provocation test is performed, in which prolactin secretion is stimulated by thyrotropin releasing hormone (1).

In view of the numerous modern determination methods for serum prolactin, the reference ranges for any study should be determined with the method adopted for that study $(4,5)$.
The aim of the investigation was:

1) to determine the reference ranges for serum prolactin in healthy neonates, infants, children and adolescents;

2) to test for significant sex differences in serum prolactin concentration within the reference groups; and

3) to test for significant differences in serum prolactin concentration between the reference groups.

\section{Materials and Methods}

Prolactin was determined in the sera of 686 healthy neonates, infants, children and adolescents (age range 5 days to 18 years). In the course of routine screening for hypothyreosis venous blood was taken from 5-day-old neonates. For all other probands blood samples wer taken after written consent was obtained from their parents, who were informed as to the purpose of the tests. The Ethics Commission of the Medical School of Erfurt gave its agreement for this purpose. The age composition 
Tab. 1. Age composition of the proband collective for the determination of reference ranges of prolactin in neonates, infants, children and adolescents

\begin{tabular}{|c|c|c|}
\hline Group & Age & $\mathrm{n}$ \\
\hline $\begin{array}{l}1 \hat{\sigma} \\
1 \%\end{array}$ & $\begin{array}{l}\text { 5th day } \\
5 \text { th day }\end{array}$ & $\begin{array}{l}70 \\
70\end{array}$ \\
\hline 1 & 5th day & 140 \\
\hline $\begin{array}{l}20 \\
29\end{array}$ & $\begin{array}{l}2-12 \text { month } \\
2-12 \text { months }\end{array}$ & $\begin{array}{l}14 \\
11\end{array}$ \\
\hline 2 & $2-12$ months & 25 \\
\hline $\begin{array}{l}35 \\
39\end{array}$ & $\begin{array}{l}2-3 \text { years } \\
2-3 \text { years }\end{array}$ & $\begin{array}{l}18 \\
16\end{array}$ \\
\hline 3 & $2-3$ years & 34 \\
\hline $\begin{array}{l}4 \sigma^{2} \\
4 \stackrel{9}{ }\end{array}$ & $\begin{array}{l}4-6 \text { years } \\
4-6 \text { yeears }\end{array}$ & $\begin{array}{l}42 \\
23\end{array}$ \\
\hline 4 & $4-6$ years & 65 \\
\hline $\begin{array}{l}50 \\
50\end{array}$ & $\begin{array}{l}7-9 \text { years } \\
7-9 \text { years }\end{array}$ & $\begin{array}{l}44 \\
41\end{array}$ \\
\hline 5 & $7-9$ years & 85 \\
\hline $\begin{array}{l}60 \\
609\end{array}$ & $\begin{array}{l}10-11 \text { years } \\
10-11 \text { years }\end{array}$ & $\begin{array}{l}44 \\
52\end{array}$ \\
\hline 6 & $10-11$ years & 96 \\
\hline $\begin{array}{l}78 \\
7 \%\end{array}$ & $\begin{array}{l}12-13 \text { years } \\
12-13 \text { years }\end{array}$ & $\begin{array}{l}44 \\
45\end{array}$ \\
\hline 7 & $12-13$ years & 89 \\
\hline $\begin{array}{l}8 \hat{0} \\
8 \stackrel{9}{9}\end{array}$ & $\begin{array}{l}14-15 \text { years } \\
14-15 \text { years }\end{array}$ & $\begin{array}{l}39 \\
38\end{array}$ \\
\hline 8 & $14-15$ years & 77 \\
\hline $\begin{array}{l}9 \hat{0} \\
9 \stackrel{9}{9}\end{array}$ & $\begin{array}{l}16-18 \text { years } \\
16-18 \text { years }\end{array}$ & $\begin{array}{l}37 \\
38\end{array}$ \\
\hline 9 & $16-18$ years & 75 \\
\hline
\end{tabular}

of the proband collective is summarized in table 1 . Individuals were included or excluded according to the criteria of Witt \& Trendelenburg (6), which permit the assembly of a reliable reference sample at a justifiable expense. Only those neonates with a birthweight between 2500 and $4000 \mathrm{~g}$ and a full term gestation time between 37 and 40 weeks were admitted to the 5 -day-old age group. Neonates with hyperbilirubinaemia were excluded, as well as those born to mothers with acute or chronic illnesses. In sexually mature girls, blood was taken during the first 10 days of the follicular phase of a monthly cycle.

\section{Test material}

About $2 \mathrm{ml}$ of blood were taken between 08.00 and $10.00 \mathrm{am}$, from an arm or skull vein, using safety monovettes from Sarstedt, Nümbrecht. Blood samples were centrifuged immediately for $5 \mathrm{~min}$ at $3000 \mathrm{~min}^{-1}$. The serum was removed with a pipette, then frozen at $-22^{\circ} \mathrm{C}$ until analysed.

\section{Method}

Prolactin was determined by a microparticle enzyme immunoassay, using the IMx from Abbott Laboratories. Cross reactivities of the test, as quoted by the manufacturer, are shown in table 2. The stated test sensitivity was $0.6 \mu \mathrm{g} / \mathrm{l}$. The method was calibrated with the WHO 2nd International Standard 83/ $562(1 \mu \mathrm{g} / \mathrm{l}$ prolactin corresponds to $24 \mathrm{mU} / \mathrm{l}$ WHO standard).

Tab. 2. Cross reactivities reported by the manufacturer for the test used on the IMx (concentration of each tested substance in brackets)

\begin{tabular}{ll}
\hline Test & Cross reactivity \\
\hline IMx Prolactin & with follitropin $(5000 \mathrm{mU} / \mathrm{l}):$ none \\
& with thyrotropin $(20000 \mathrm{mU} / \mathrm{l}):$ none \\
& with human chorionic gonadotropin \\
& $(100000 \mathrm{U} / \mathrm{l}):$ none \\
& with lutropin $(5000 \mathrm{U} / \mathrm{l}):$ none \\
& with gonadotropin $(1000 \mu \mathrm{g} / \mathrm{l}): 0.039 \%$ \\
& with human placental lactogen \\
& $(100000 \mu \mathrm{g} / \mathrm{l}):$ none
\end{tabular}

\section{Quality control}

For the control of precision from day to day, standards (from Abbott Laboratories) of low, intermediate and high concentration were included intermittently in each series. As a measure of the relative methodical error, the arithmetic mean $(\bar{x})$, standard deviation (s) and coefficient of variation (CV) were calculated from the individual results of these control series. Precision in series was monitored once, using calibrators " $B$ " and " $E$ " of low and high concentrations from Abbott Laboratories. Again, the arithmetic mean $(\overline{\mathrm{x}})$, standard deviation (s) and the coefficient of variation $(\mathrm{CV})$ were calculated from the individual results.

\section{Statistical evaluation of the results}

The results were first presented as separate histograms for each age group and for each sex. The type of distribution was determined with the Kolmogorov-Smirnov test. If the resulting error probability was below the stated value of $\alpha=0.05$, the distribution was assumed to be normal. If the distribution was not normal, the 2.5 th, 50th and 97.5 th percentiles were determined for that reference group (7). In each age group, the values for prolactin were tested for significant sex differences, using the U-test of Mann \& Whitney, again using a limiting value of $\alpha=0.05$ for the error probability. In the absence of a significant sex-related difference, males and females were subsequently treated as a single group. The U-test of Mann \& Whitney was also used to test for significant differences between age groups, and all groups showing no significant difference were combined. The median value and reference range for serum prolactin were calculated for all the final combinations of reference groups.

The degree of any linear relationship between age and serum prolactin concentration was determined by calculation of the correlation coefficient, $r$.

\section{Results}

Prolactin was determined in the serum of 686 healthy probands (352 males, 334 females). Figure 1 gives an overview of the results for all groups before significance testing. Significant differences between the sexes 


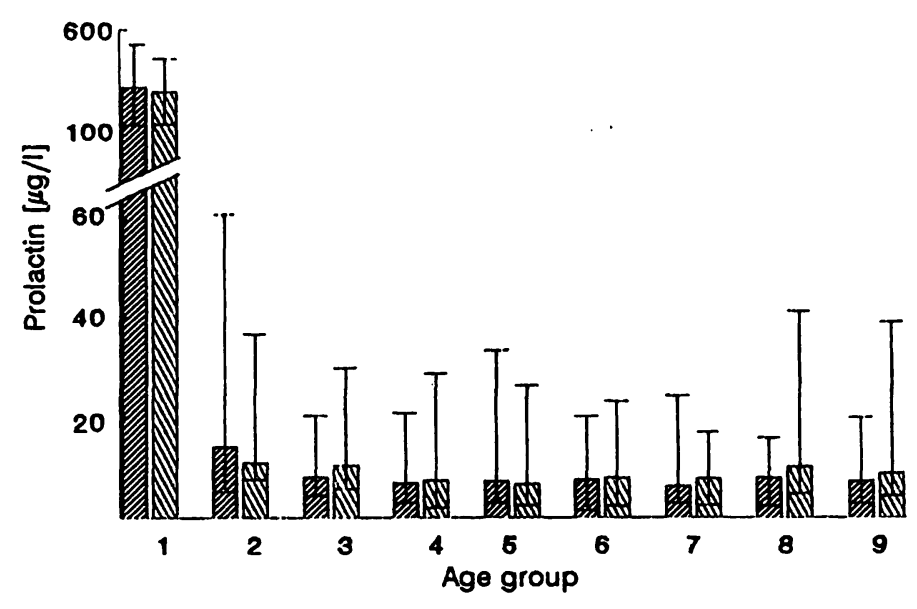

Fig. 1. 50th Percentiles and 95\% intervals for the concentrations of prolactin $(\mu \mathrm{g} / \mathrm{l})$ in the serum of age groups $1-9$ (see tab. 1).

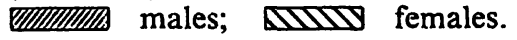

were found in age groups 7,8 and $9(p=0.0091$, $\mathrm{p}=0.0012$ and $\mathrm{p}=0.0271$, respectively).

All reference groups were tested for significant differences, using the U-test of Mann \& Whitney. Although the prolactin values of $12-13$-year-old males and the 12-13-year-old females were not significantly different, these two groups were kept separate.

Table 3 shows the new groups formed after significance testing. The median value and reference range for serum prolactin were recalculated for each new group combination.

A correlation analysis was performed for the relationship between proband age and the serum concentration of prolactin. A significant negative correlation was found ( $p<0.001$ ), i.e. the concentration of serum prolactin decreased with increasing age $(\mathrm{r}=-0.5927)$.

\section{Quality control}

Results of the quality control are shown in table 4 . The variation coefficients within series and between series were all less than $8 \%$.
Tab. 4. Results for the control of precision from day to day and in series

\begin{tabular}{llllll}
\hline & Control serum & $\mathrm{n}$ & $\begin{array}{l}\overline{\mathrm{x}} \\
{[\mu \mathrm{g} / \mathrm{l}]}\end{array}$ & $\begin{array}{l}\mathrm{s} \\
{[\mu \mathrm{g} / \mathrm{l}]}\end{array}$ & $\begin{array}{l}\mathrm{CV} \\
{[\%]}\end{array}$ \\
\hline Control from & Abbott L & 18 & 7.95 & 0.61 & 7.67 \\
day to day & Abbott M & 41 & 20.5 & 1.20 & 5.86 \\
& Abbott H & 21 & 40.9 & 2.41 & 5.89 \\
& & & & & \\
Control in & "B" calibrator & 23 & 4.66 & 0.14 & 2.94 \\
series & "E" calibrator & 23 & 69.2 & 1.66 & 2.40 \\
\hline
\end{tabular}

\section{Discussion}

For the correct evaluation of the reported serum prolactin concntration, reference ranges must be established. Most modern immunometric assays have so far been used to determine reference ranges for adults, but usually not for children. Childhood reference ranges for serum prolactin, determined with the present method, have not been reported in the literature.

Reported reference ranges $(8,9)$ for childhood, using other methods, are shown in table 5.

The data shown in table 5 are not comparable with the present results, because:

1) other methods were used;

2) different age classifications were used;

3) the numbers of probands in each age group were not reported;

4) no data were reported on the type of distribution of the reference values;

5) information was sometimes lacking on the reference preparation used for calibration purposes.

In the present study, 686 neonates, infants, children and adolescents (age range: 5 days to 18 full years) were used to determine the reference ranges of serum

Tab. 3. 50th Percentile, $95 \%$ interval, minimal value and maximal value for the serum concentration of prolactin in neonates, infants, children and adolescents (values in $\mu \mathrm{g} / \mathrm{l}$ )

\begin{tabular}{|c|c|c|c|c|c|c|}
\hline Age & Sex & $\mathbf{n}$ & $\begin{array}{l}\text { Median } \\
\text { (50th percentile) }\end{array}$ & $\begin{array}{l}\text { Normal (95\% } \\
\text { scatter range } \\
\text { (2.5-97.5th } \\
\text { percentiles) }\end{array}$ & Minimum & Maximum \\
\hline $\begin{array}{l}5 \text { days } \\
2-12 \text { months } \\
2-3 \text { years } \\
4-11 \text { years } \\
12-13 \text { years } \\
12-13 \text { years } \\
14-18 \text { years } \\
14-19 \text { years }\end{array}$ & $\begin{array}{l}0 / 9 \\
019 \\
019 \\
0 / 9 \\
019 \\
019 \\
0 \\
0 \\
0 \\
0 \\
0 \\
1\end{array}$ & $\begin{array}{r}140 \\
25 \\
34 \\
246 \\
44 \\
45 \\
76 \\
76\end{array}$ & $\begin{array}{c}238 \\
12.4 \\
9.85 \\
7.20 \\
6.20 \\
7.80 \\
7.35 \\
9.50\end{array}$ & $\begin{array}{c}102-496 \\
5.30-63.3 \\
4.40-29.7 \\
2.63-21.0 \\
2.84-24.0 \\
2.52-16.9 \\
2.76-16.1 \\
4.20-39.0\end{array}$ & $\begin{array}{l}95.7 \\
5.3 \\
4.40 \\
1.3 \\
2.8 \\
2.40 \\
2.30 \\
4.20\end{array}$ & $\begin{array}{l}600 \\
63.3 \\
29.7 \\
33.9 \\
25.7 \\
17.0 \\
19.7 \\
41.2\end{array}$ \\
\hline
\end{tabular}


Tab. 5. Reference ranges reported in the literature for the concentration of prolactin in serum

\begin{tabular}{|c|c|c|c|c|c|c|}
\hline Author & Method & \multicolumn{2}{|c|}{ Age groups } & No. of probands & $\begin{array}{l}\text { Type of distribution } \\
\text { and scatter range }\end{array}$ & Normal range \\
\hline \multirow[t]{2}{*}{$\begin{array}{l}\text { Sitzmann. } \\
1986 \\
(8)\end{array}$} & $\begin{array}{l}\text { No data } \\
(\mu \mathrm{g} / \mathrm{l})\end{array}$ & \multicolumn{2}{|c|}{$\begin{array}{l}\text { Neonates, } 1 \text { st week } \\
\text { Age } 6 \text { weeks } \\
\text { Prepuberty } \\
\text { Adolescence }\end{array}$} & No data & $\begin{array}{l}\text { No data } \\
\text { Median value } \\
\text { given } \pm S D\end{array}$ & $\begin{array}{l}76 \pm 36 \\
17 \pm 6 \\
11 \pm 4 \\
14 \pm 5\end{array}$ \\
\hline & $\begin{array}{l}\text { No data } \\
\text { hPRL*) } \\
\text { Lewis } 203\end{array}$ & \multicolumn{2}{|c|}{$\begin{array}{l}\text { Infants, } 1-5 \text { months } \\
\text { Children, } 1-2 \text { years } \\
\text { Girls, } 4-17 \text { years } \\
\text { Puberty stage } 1 \\
\text { Puberty stage } 2 \\
\text { Puberty stage } 3 \\
\text { Puberty stage } 4 \\
\text { Puberty stage } 5 \\
\text { Boys, } 5-7 \text { years }\end{array}$} & No data & $\begin{array}{l}\text { No data } \\
\text { Median value } \\
\text { given } \pm \text { SD } \\
\text { No clear data } \\
\text { on scatter range }\end{array}$ & $\begin{array}{r}10.0 \pm 1.9(6.1-15) \\
6.0 \pm 1.0(2.3-12) \\
7.1 \pm 1.2(2.9-18) \\
9.0 \pm 1.3(4.6-12) \\
4.1 \pm 1.1(2.7-7.4) \\
6.9 \pm 0.8(4.8-9.2) \\
7.4 \pm 0.8(3.3-19) \\
6.0 \pm 0.5(1.7-16)\end{array}$ \\
\hline \multirow[t]{2}{*}{$\begin{array}{l}\text { Plenert } \\
\& \text { Heine } \\
1984 \\
(9)\end{array}$} & $\begin{array}{l}\text { RIA } \\
\left(10^{3} / U / 1\right)\end{array}$ & & $\begin{array}{l}1 \text { day } \\
6 \text { days } \\
12-23 \text { days } \\
3-7 \text { months } \\
2 \text { years } \\
6-7 \text { years } \\
8-9 \text { years } \\
10-11 \text { years } \\
12-13 \text { years } \\
14-16 \text { years }\end{array}$ & No data & No data & $\begin{array}{r}6899 \pm 3622 \\
3358 \pm 1171 \\
1675 \pm 700 \\
312 \pm 127 \\
290 \pm 289 \\
188 \pm 113 \\
265 \pm 116 \\
110 \pm 56 \\
116 \pm 103 \\
188 \pm 199\end{array}$ \\
\hline & & & $\begin{array}{l}1 \text { day } \\
6 \text { days } \\
12-23 \text { days } \\
3-7 \text { months } \\
2 \text { years } \\
6-7 \text { years } \\
8-9 \text { years } \\
10-11 \text { years } \\
12-13 \text { years } \\
14-16 \text { years }\end{array}$ & & & $\begin{array}{r}9640 \pm 4711 \\
2709 \pm 1300 \\
1851 \pm 475 \\
355 \pm 221 \\
228 \pm 203 \\
218 \pm 172 \\
251 \pm 114 \\
266 \pm 165 \\
216 \pm 153 \\
241 \pm 139\end{array}$ \\
\hline
\end{tabular}

*) human prolactin

prolactin in childhood. The probands were first divided into 18 groups according to age and sex (see tab. 1). The chosen age classification was based on the suggestions of Egger et al. (10) and the recommendations of the International Federation of Clinical Chemistry (11). The neonatal age of 5 days was chosen simply because the use of this age for other diagnostic studies (e.g. hypothyreosis screening) means that proband material is readily available. In contrast, no probands were available between the ages of 6 and 30 days. Also, data from the 2-12-monthold male and female infants have limited interpretative value, due to the small numbers of probands in these groups.

The analytical method was a microparticle enzyme immunoassay (MEIA). Advantages of this method are its speed, its requirement for only a small sample volume, and the absence of radioactive isotopes.

Extraordinarily high concentrations of prolactin were found in the sera of 5-day-old neonates. No sex dif- ferences were detectable up to the age of 11 years. From the age of 14 years onwards, the serum prolactin concentration was significantly higher in females than in males.

Tab. 6. Reference ranges for prolactin in the serum of neonates, infants, children and adolescents $(\mu \mathrm{g} / \mathrm{l})$

\begin{tabular}{lc} 
Males & \\
Sth day & 102 \\
$2-12$ months & $5.30-63.3$ \\
$2-3$ years & $4.40-29.7$ \\
$4-11$ years & $2.63-21.0$ \\
$12-13$ years & $2.84-24.0$ \\
$14-18$ years & $2.76-16.1$ \\
Females & \\
Sth day & \\
$2-12$ months & $102-496$ \\
$2-3$ years & $5.30-63.3$ \\
$4-11$ years & $4.40-29.7$ \\
$12-13$ years & $2.63-21.0$ \\
$14-18$ years & $2.52-16.9$ \\
\hline
\end{tabular}


A significant negative correlation was found between age and serum prolactin concentration, i.e. serum prolactin decreased with increasing age. This statistical result, however, is due primarily to the extremely high concentrations measured in 5-day-old neonates.

In accordance with the recommendations of the International Federation of Clinical Chemistry, the $95 \%$ scatter range was taken as the normal range. Since the values of most reference groups do not show a normal distribution, the reference range was reported

\section{References}

1. Derricks-Tan, J. S. E. (1988) Grundlagen der ProlaktinDiagnostik. 1. Auflage, Schattauer, Stuttgart, New York.

2. Benker, G., Jaspers, C., Häusler, G. \& Reinwein, D. (1990) Control of prolactin secretion. Klin. Wochenschr. 68 , 1157-1167.

3. Rosenfield, R. L. (1990) The ovary and female sexual maturation. In: Clinical Pediatric Endocrinology. Second Edition (Kaplan, S. A.) W. B. Saunders Company, Philadelphia, London, Toronto, Montreal, Sydney, Tokyo.

4. Haro, L. S., Lee, D. W., Singh, R. N. P., Bee, G., Markoff, E. \& Lewis, U. J. (1990) Glycosylated human prolactin: Alterations in glycosylation pattern modify affinity for lactogen receptor and values in prolactin radioimmunoassay. J. Clin. Endocrinol. Metab. 7, 379-383.

5. Kunkel, S., Rudolf, K., Woltanski, K.-P. \& Büttner, S. (1990) Heterologe und homologe Radioimmunoassays für humanes Prolaktion. 1. Mitteilung: Aufbau und Methodenkritik. Zent.bl. Gynäkol. 112, 535-544.

6. Witt, J. \& Trendelenburg, C. (1982) Gemeinsame Studie zur Erstellung von Richtwerten klinisch-chemischer Kenngrößen im Kindesalter. J. Clin. Chem. Clin. Biochem. 20, $235-242$. as the 2.5th and 97.5th percentiles, together with the median value (50th percentile).

Where possible, groups showing no significant differences after significance testing were combined. These final group combinations and their respective reference ranges are shown in table 6.

\section{Acknowledgement}

The authors wish to thank Mrs. $R$. Biesenbach for technical assistance. We also thank Abbott Laboratories for their generous support, which made this work possible.
7. International Federation of Clinical Chemistry Scientific Committee, Clinical Section Expert Panel on Theory of References Values and International Committee for Standardisation in Haematology. Standing Comittee on Reference Values (1987) Approved recommendation (1987) on the theory of reference values. Part 5. Statistical treatment of collected reference values. Determination of reference limits. J. Clin. Chem. Clin. Biochem. 25: 645-656.

8. Sitzmann, F. C. (1986) Normalwerte. 2. Auflage, Hans Marseille, München.

9. Plenert, W. \& Heine, W. (1984) Normalwerte. 6. Auflage, Verlag Volk und Gesundheit, Berlin

10. Egger, E., Dummler, W., Neymeyer, H.-G., Schwarze; H. \& Scholz, R. (1987) Vorschlag zum Arzneibuch der DDR, Diagnostische Laboratoriumsmethoden, AB (D. L.)-DDR 89. Allgemeines. Referenzbereiche. Zent.bl. Pharm. 126, $737-747$.

11. International Federation of Clinical Chemistry Scientific Committee, Clinical Section Expert Panel on Theory of Reference Values (1987) Approved recommendation (1987) on the theory of reference values. Part 2. Selection of individuals for the production of reference values. J. Clin. Chem. Clin. Biochem. 25, 639-644.

Doz. Dr. med. habil. Gudrun Wiedemann Klinik und Poliklinik für Kindermedizin der Medizinischen Hochschule Erfurt Am Schwemmbach 32 a D-99099 Erfurt Bundesrepublik Deutschland 
